\title{
Cultural, Morphological and Pathogenic Variability of Different Isolates of Sclerotium rolfsii Obtained from Rice-Tomato-Rice Cropping System of Undulating Red and Lateritic Zone of West Bengal, India
}

\author{
Asish Mahato and Mohan Kumar Biswas* \\ Department of Plant Protection, Palli-Siksha Bhavana, Visva-Bharati, Sriniketan, \\ West Bengal - 731236, India \\ *Corresponding author
}

\begin{abstract}
Keywords
Sclerotium rolfsii, Tomato, Cultural, Morphological, and Pathogenic Variability.

Article Info

Accepted:

24 February 2017 Available Online: 10 March 2017
\end{abstract}

\section{A B S T R A C T}

\section{Introduction}

Sclerotium rolfsii, casual agent of collar rots disease of Tomato (Solanum lycopersicum L.), is a soil borne plant pathogen. It is highly polyphagus, non-target, soil inhabitant, moisture loving, sclerotia and basidia producing, ubiquitous facultative parasitic basidiomycetes fungi which produces oxalic acid, polygalacturonase and cellulose as pathogenic weapons. The fungus was first reported by Rolfs (1892) as a cause of tomato blight from Florida in U.S.A. Saccardo (1911) named the fungus as $S$. rolfsii sp. nov. The fungis is distributed in tropical and subtropical regions of the world where high temperatures prevail. Cooper (1961) has termed Sclerotium rolfsii as a omnipathogenic fungus, as it possesses the ability to attack a large number of monocot and dicot plant 
species, belonging to about 100 families. According to Tu (1978) and Wydra (1996), Sclerotium rolfsii is more severe on legumes, solanaceous crops, cucurbits and other vegetables grown in rotation with beans. This is one of the most destructive and common pathogen of tomato crop causing collar-rot disease in undulating red and lateritic zone of West Bengal. There are several reports of S.rolfsii where significant variations in morphological behavior were observed (Sharma et al., 2002). Variability among $S$. rolfsii populations from different geographical regions was demonstrated by several workers (Harlton et al., 1995, Okabe et al., 1998, Sarma et al., 2002). To understand the ecology, pathogenicity, epidemiology and evolutionary potential aspects of the $S$. rolfsii, it is essential to study about the cultural, morphological and pathogenic variability of the $S$. rolfsii present in undulating red and lateritic zone of West Bengal. Therefore, the present study was undertaken with a view to study the morphological, cultural and pathogenic variability's among isolates of $S$. rolfsii collected from tomato plants of different geographic locations.

\section{Materials and Methods}

A roving survey was carried out during 201415 in undulating red and lateritic zone of West Bengal which consist Birbhum, Bankura, Purulia Pachim Medinapur and some part of Burdwan district where tomato crops are grown exclusively by the farmers and collar rot infected plant were collected. These diseased materials were kept in sterilized polythene begs and brought to the laboratory for the purpose of isolation of the pathogen.

\section{Isolation of pathogen}

Sclerotium rolfsii was isolated from the stems of infected tomato plants by tissue segment method (Rangaswami and Mahadevan, 1999) on potato dextrose agar (PDA) medium. The plant specimens were washed with tap water, small pieces of tissue of about 0.5 to $1 \mathrm{~cm}$ from infected collar region with some healthy tissue were cut with sterile scalpel. The pieces were surface sterilized with $0.01 \%$ mercuric chloride solution for about 30 seconds and rinsed in sterilized water for three times subsequently to eliminate all the traces of mercuric chloride and then dried between folds of sterilized filter paper. After that the surface sterilized pieces were transferred onto PDA medium in Petri dishes. Plates were incubated at $27 \pm 1^{\circ} \mathrm{C}$ and observed periodically for growth of the fungus. The colony of the fungal pathogens grew from the infected pieces were isolated. The fungal isolates were purified following hyphal tip technique (Tuite, 1969), identified based on its mycelia and sclerotial characters (Barnett and Hunter, 1972). Repeated culture has been done from tip of the single hypha to obtain pure culture of the identified Sclerotium rolfsii and the pure culture was stored in the PDA slants at $10^{\circ} \mathrm{C}$ for further use.

\section{Pathogenic Variability}

\section{Pathogenicity test}

The pathogenicity of different isolates, collected from different regions was carried out through pot culture experiment by soil infestation method in shade condition. Inocula of the different selected isolates of S. rolfsii were prepared on autoclaved moist wheat grains in $500 \mathrm{ml}$ Erlenmeyer flask. Sterilized soil was taken in plastic pots of size $45 \mathrm{~cm} \mathrm{x}$ $30 \mathrm{~cm}$. One month old healthy tomato seedling (var- Punjab Chuhara) was transplanted singly in each pots and after few days when seedling get well established, the inocula of different isolates were incorporated in collar region at the rate of $20 \mathrm{~g} / \mathrm{kg}$ soil in five selected pots separately. Pots without inoculation were 
served as control for each case. Soil moisture was maintained properly by adding nonsterile filtered tap water throughout the period. The inoculated plants were observed daily. As soon as the disease symptoms were evident, the pathogen was again re-isolated to confirm the infectivity of the isolated pathogen. The plants showing typical wilting symptoms were recorded subsequently.

On the basis of wilt symptom observed of plant, isolates were graded different category. Grads were as minus (-) for no symptom and plus (+) for wilt symptom in inoculated pot. Appearance of symptom was again divided into four groups viz., up to $25 \%$ wilt ranked as single plus (+), 25.1 to $50 \%$ ranked as double plus $(++), 50.1$ to $75 \%$ were ranked triple plus $(+++)$ and more than $75 \%$ were ranked tetra plus sign (++++) after 15 days of inoculation and reacted as slow pathogenic, moderate pathogenic, pathogenic and highly pathogenic isolates respectively.

\section{Host range study}

The host range of Sclerotium rolfsii, causal agents of tomato collar rot disease was studied by artificial inoculation to different plant species in pot culture experiments in in vitro condition. Sterilized soil was taken in plastic pots of size $45 \mathrm{~cm}$ x $30 \mathrm{~cm}$. Thirty days old apparently healthy seedlings of Brinjal, Lady's finger; Chilli and Maize were transplanted in such pots. Whereas, groundnut seeds, potato tubers, elephant foot yam corms, Bitter gourd, Ridge gourd, Bean, Zinger, Onion, Gram and Berseem were sown/planted separately in five numbers of plastic pots and after 25 days of emergence of seedlings said amount of inoculums was incorporated in each pots. Pots without inoculum were served as control for each case. Soil moisture was maintained properly by adding non-sterile filtered tap water throughout the period. The plants showing typical wilting symptoms were recorded subsequently. The pots of each host were examined regularly upto 15 days and symptoms in the plants were noted and compared with the un-inoculated plants of control pots. Finally after 15 days, the degree of infection was categorized as given in Table-1 according to the collar region lessoning of the plants (Chaurasia et al., 2014).

\section{Cultural and Morphological Variability}

Variability in cultural and morphological character i.e. mycelial growth rate, colony color, appearance and sclrotial color, shape, arrangement, weight, maturity and number of sclerotia production of different isolates were studied by using Potato Dextrose Agar (PDA) medium. The mycelia disc of $4 \mathrm{~mm}$ diameter of each isolate was taken from the actively growing cultures and centrally placed on 90 $\mathrm{mm}$ Petri plates containing sterilized PDA medium and inoculated at at $26 \pm 1{ }^{\circ} \mathrm{C}$ for 15 days. Each isolate was replicated three times. Day to day cultural and morphological characters was recorded upto 15 day of inoculation.

\section{Results and Discussion}

\section{Pathogenic Variability}

\section{Pathogenicity test}

The result of pathogenicity test of different isolates of $S$. rolfsii which were collected from different region of undulating red and lateritic zone of West Bengal is presented in Table -2. All isolates reviled some degree of pathogenic reaction to tomato seedling. Among the ten isolates three isolates i.e. SRPU-1, SRPU-2 and SRPM-1 showed highly pathogenic reaction, three isolates i.e. SRBN-2, SRBW-1 and SRPM-2 showed pathogenic reaction, three isolates i.e. SRBN1, SRBR-2 and SRBW-2 showed moderate 
pathogenic reaction and one isolate SRBR-1 showed slow pathogenic reaction with the Tomato seedlings.

\section{Host range study}

The results of host rang study is presented in Table -3. Results of the host range study clearly showed that all selected crop species are susceptible to the tomato collar rot causing pathogen Sclerotium rolfsii. Among the fifteen crop species Brinjal (Solanum melongena L.), Potato (Solanum tuberosum L.), Chilli (Capsicum annum), Zinger (Zingerber officinalis), Onion (Allium cepa. L), Gram (Cicer arietinum) and Berseem (Trifolium alexandrium) were found to be most susceptible for the disease, as maximum degree of infection have been recorded in them and these plants were completely collapsed within 15 days after inoculation. Out of them, crops like Groundnut (Arachis hypogaea), Lady's finger (Abelmoschus esculentus), Bitter gourd (Momordica charantia L.), Ridge gourd (Luffa acutangula L), Bean (Dolichos lablab), Maize (Zea mays) and Elephant foot yam (Amorphophallus paeoniifolius) were showed Moderate degree of susceptibility where as Wheat (Triticum vulgare) was showed poor degree of susceptibly against the tomato collar rot causing pathogen.

\section{Cultural and Morphological Variability}

Different cultural and morphological characters of ten isolates of S.rolfsii were studied based on mycelial and sclerotial parameters. The result of cultural and morphological characters study presented in table -4 and table -5 . The mycelial growth rate on PDA medium was very fast in isolate SRPU-1 isolated from Raghunathpur-1 block of Purulia district, SRPU-2 isolated from Hura block of Purulia district and SRPM-1 isolated from Binpur block of Paschim Medinapur district. The isolate SRBR-1 which was isolated from Labpur block of Birbhum district showed Slow growth reaction. Three isolates i.e. SRBN-2 isolated from Gangajalghati block of Bankura district, SRBW-1 isolated from Raniganj block of Burdwan district and SRPM-2 isolated from Garbeta block of Paschim Medinapur district showed fast mycelial growth reaction on PDA medium. The isolates like SRBN-1 isolated from Chatana block of Bankura district, SRBR-2 isolated from Bolpur block of Birbhum district and SRBW-2 isolated from Pandebeswar block of Burdwan district showed Moderate type growth reaction on PDA medium.

All isolates produced light white to dull white mycelial colony on PDA medium. All isolates of S.rolfsii differed in their mycelia dispersion and appearance in Petri plates. All isolates showed dispersed growth all over the plate to aggregated fashion and their appearance was loose to dense cottony with sparse or fluffy mycelium. Isolates SRBR-1, SRBW-2 and SRBW-1 were produced aggregated dispersion of mycelium on PDA media (Table 5). Similar, reports were given by Rakholiya et al., (2011) and Kumar et al., (2014) studied cultural and morphological variability of S.rolfsii and reported considerable variability in mycelial and sclerotial dimensions.

Among the morphological characters sclerotial shape were varies from oval to irregular. The five numbers of isolates i.e. SRPU-1, SRPU-2, SRBR-1, SRBW-1 and SRPM-2 were produce spherical sclerotia and three numbers of isolates i.e. SRBN-1, SRBN-2 and SRBW-2 produce oval sclerotia where as isolates SRBR-2 and SRPM-1 were produced Irregular sclerotia. Sclerotia were light brown to dark brown in colour. 
Table.1 Degree of infection of plants

\begin{tabular}{|l|c|c|}
\hline \multicolumn{1}{|c|}{ Lesioning on basal part of plants } & Degree of infection & Symbol \\
\hline Healthy plant (no lesioning) & No infection & 0 \\
\hline Initial lesioning & Poor infection & $1+$ \\
\hline $\begin{array}{l}\text { Heavy basal } \\
\text { lesioning }\end{array}$ & Moderate infection & $2+$ \\
\hline Collapsed plant & Highly infection & $3+$ \\
\hline
\end{tabular}

Table.2 Pathogenic variability Sclerotium rolfsii of isolates

\begin{tabular}{|c|c|c|c|c|}
\hline $\begin{array}{l}\text { S. } \\
\text { No. }\end{array}$ & Isolate & Location & G.P.S Location & Pathogenicity \\
\hline 1. & SRPU-1* & Purulia, Raghunathpur-1 & $\begin{array}{l}\text { N } 23^{0} 31^{\prime} 9.74^{\prime \prime} \\
\text { E } 86^{\circ} 40^{\prime} 56.41^{\prime \prime}\end{array}$ & +++ \\
\hline 2. & SRPU-2 & Purulia, Hura & $\begin{array}{l}\text { N } 23^{0} 17^{\prime} 27.41^{\prime \prime} \\
\text { E } 86^{0} 37^{\prime} 28.74^{\prime \prime}\end{array}$ & ++++ \\
\hline 3. & SRBN-1 & Bankura, Chatana & $\begin{array}{l}\mathrm{N} 23^{0} 18^{\prime} 22.17^{\prime \prime} \\
\text { E } 86^{0} 58^{\prime} 0.74^{\prime \prime}\end{array}$ & ++ \\
\hline 4. & SRBN-2 & Bankura, Gangajalghati & $\begin{array}{l}\text { N } 23^{0} 25^{\prime} 17.78^{\prime \prime} \\
\text { E } 87^{\circ} 6^{\prime} 39.67^{\prime \prime}\end{array}$ & +++ \\
\hline 5. & SRBR-1 & Birbhum, Labpur & $\begin{array}{l}\text { N } 23^{\circ} 49^{\prime} 18.96^{\prime \prime} \\
\text { E } 87^{\circ} 47^{\prime} 28.22^{\prime \prime}\end{array}$ & + \\
\hline 6. & SRBR-2 & Birbhum, Bolpur & $\begin{array}{l}\text { N } 23^{0} 39^{\prime} 56.14^{\prime \prime} \\
\text { E } 87^{0} 37^{\prime} 57.21^{\prime \prime}\end{array}$ & ++ \\
\hline 7. & SRBW-1 & Burdwan, Raniganj & $\begin{array}{l}\mathrm{N} 23^{0} 38^{\prime} 55.31^{\prime \prime} \\
\text { E } 87^{0} 5^{\prime} 31.69^{\prime \prime}\end{array}$ & +++ \\
\hline 8. & SRBW-2 & Burdwan, Pandebeswar & $\begin{array}{l}\text { N } 23^{\circ} 42^{\prime} 36.34^{\prime \prime} \\
\text { E } 87^{1} 16^{\prime} 25.78^{\prime \prime}\end{array}$ & ++ \\
\hline 9. & SRPM-1 & Paschim Medinapur, Binpur & $\begin{array}{l}\mathrm{N} 22^{0} 34^{\prime} 43.59^{\prime \prime} \\
\text { E } 87^{0} 0^{\prime} 16.55^{\prime \prime}\end{array}$ & +++ \\
\hline 10 & SRPM-2 & Paschim Medinapur, Garbeta & $\begin{array}{l}\mathrm{N} 22^{0} 52^{\prime} 18.67^{\prime \prime} \\
\text { E } 87^{0} 21^{\prime} 39.48^{\prime \prime}\end{array}$ & +++ \\
\hline
\end{tabular}

*SR: Sclerotium rolfsii, PU: Purulia, BN: Bankura, BR: Birbhum, BW: Burdwaman, PM: Paschim Medinapur. 
Table.3 Host range of Sclerotium rolfsii under artificial inoculation

\begin{tabular}{|c|c|c|}
\hline S.No & Host & Degree of infection \\
\hline 1 & Brinjal (Solanum melongena L.) & $3+$ \\
\hline 2 & Potato (Solanum tuberosum L.) & $3+$ \\
\hline 3 & Groundnut (Arachis hypogaea) & $2+$ \\
\hline 4 & Lady's finger (Abelmoschus esculentus) & $3+$ \\
\hline 5 & Chilli (Capsicum annum) & $2+$ \\
\hline 6 & Bitter gourd (Momordica charantia L.) & $2+$ \\
\hline 7 & Ridge gourd ( Luffa acutangula L) & $2+$ \\
\hline 8 & Bean (Dolichos lablab) & $3+$ \\
\hline 9 & Zinger (Zingerber officinalis $)$ & $3+$ \\
\hline 10 & Onion (Allium cepa L) & $2+$ \\
\hline 11 & Maize(Zea mays) & $3+$ \\
\hline 12 & Gram (Cicer arietinum) & $3+$ \\
\hline 13 & Berseem (Trifolium alexandrium) & $1+$ \\
\hline 14 & Wheat (Triticum vulgare) & $2+$ \\
\hline 15 & Elephant foot yam (Amorphophallus paeoniifolius) & \\
\hline
\end{tabular}

Table.4 Growth rate of different isolates of Sclerotium rolfsii on PDA media

\begin{tabular}{|c|c|c|c|c|c|c|c|}
\hline \multirow{2}{*}{ S. No. } & \multirow{2}{*}{ Isolate } & \multirow{2}{*}{ Location } & \multicolumn{4}{|c|}{ Growth rate $(\mathrm{cm})$} & \multirow[t]{2}{*}{ Reaction } \\
\hline & & & $24 \mathrm{hr}$ & $48 \mathrm{hr}$ & $72 \mathrm{hr}$ & $96 \mathrm{hr}$ & \\
\hline 1 & SRPU-1 & Purulia, Raghunathpur-1 & 2.6 & 5.6 & 7.6 & 9 & Very Fast \\
\hline 2 & SRPU-2 & Purulia, Hura & 2.6 & 5.4 & 7.5 & 9 & Very Fast \\
\hline 3 & SRBN-1 & Bankura, Chatana & 1.2 & 3.6 & 4.2 & 5.4 & Moderate \\
\hline 4 & SRBN-2 & Bankura, Gangajalghati & 1.7 & 4.2 & 6.8 & 8.7 & Fast \\
\hline 5 & SRBR-1 & Birbhum, Labpur & 0.5 & 1.2 & 2 & 2.7 & Slow \\
\hline 6 & SRBR-2 & Birbhum, Bolpur & 1 & 2.8 & 4.6 & 5.8 & Moderate \\
\hline 7 & SRBW-1 & Burdwan, Raniganj & 1.5 & 3.8 & 6.4 & 8.6 & Fast \\
\hline 8 & SRBW-2 & Burdwan, Pandebeswar & 1.3 & 3.6 & 4.5 & 5.7 & Moderate \\
\hline 9 & SRPM-1 & $\begin{array}{l}\text { Paschim } \\
\text { Binpur }\end{array}$ & 2.8 & 5.8 & 8 & 9 & Very Fast \\
\hline \multirow[t]{3}{*}{10} & SRPM-2 & $\begin{array}{l}\text { Paschim Medinapur, } \\
\text { Garbeta }\end{array}$ & 1.6 & 4 & 6 & 8.2 & Fast \\
\hline & $\operatorname{Sem} \pm$ & & 0.11 & 0.12 & 0.22 & 0.16 & \\
\hline & Cd at $1 \%$ & & $0 . .43$ & 0.50 & 6.71 & 0.66 & \\
\hline
\end{tabular}


Table.5 Mycelial and Sclerotial Characters of Isolates of S.rolfsii on PDA Media

\begin{tabular}{|c|c|c|c|c|c|c|c|c|c|c|}
\hline \multirow{2}{*}{$\begin{array}{c}\text { S. } \\
\text { No. }\end{array}$} & \multirow[b]{2}{*}{ Isolate } & \multicolumn{3}{|c|}{ Mycelial Characters } & \multicolumn{6}{|c|}{ Sclerotial Characters } \\
\hline & & $\begin{array}{c}\text { Growth } \\
\text { Rate }\end{array}$ & $\begin{array}{l}\text { Colony } \\
\text { color }\end{array}$ & Appearance & $\begin{array}{l}\text { No./plate } \\
\text { (15 DAI) }\end{array}$ & Color & Shape & $\begin{array}{l}\mathrm{Wt} \\
(\mathrm{mg})\end{array}$ & Arrangement & $\begin{array}{l}\text { Maturity } \\
\text { (DAI) }\end{array}$ \\
\hline 1. & SRPU-1 & Very Fast & $\begin{array}{l}\text { Light } \\
\text { White }\end{array}$ & $\begin{array}{l}\text { Cottony, puffy } \\
\text { at edges, dense } \\
\text { at margins }\end{array}$ & 214.00 & $\begin{array}{l}\text { Light } \\
\text { Brown }\end{array}$ & Spherical & 6.7 & Scattered & 15 \\
\hline 2. & SRPU-2 & Very Fast & $\begin{array}{l}\text { Dull } \\
\text { White }\end{array}$ & $\begin{array}{l}\text { Sparse, thin } \\
\text { strands }\end{array}$ & 320.50 & \begin{tabular}{|l|} 
Dark \\
Brown \\
\end{tabular} & Spherical & 8.5 & Scattered & 11 \\
\hline 3. & SRBN-1 & Moderate & $\begin{array}{l}\text { Light } \\
\text { White }\end{array}$ & $\begin{array}{l}\text { Puffy at centre, } \\
\text { upright growth } \\
\text { habit }\end{array}$ & 195.00 & $\begin{array}{l}\text { Dull } \\
\text { Brown }\end{array}$ & Oval & 5.7 & Peripheral & 12 \\
\hline 4. & SRBN-2 & Fast & White & Cottony, sparse & 265.00 & \begin{tabular}{|l|} 
Dark \\
Brown \\
\end{tabular} & Oval & 6.6 & Central & 12 \\
\hline 5. & SRBR-1 & Slow & $\begin{array}{l}\text { Extra } \\
\text { White }\end{array}$ & $\begin{array}{l}\text { Upright growth } \\
\text { habit, cottony } \\
\text { \&puffy } \\
\text { aggregated }\end{array}$ & 154.00 & $\begin{array}{l}\text { Light } \\
\text { Brown }\end{array}$ & Spherical & 3.7 & Peripheral & 15 \\
\hline 6. & SRBR-2 & Moderate & White & $\begin{array}{l}\text { Suppressed, thin } \\
\text { strands }\end{array}$ & 185.00 & $\begin{array}{l}\text { Light } \\
\text { Brown }\end{array}$ & Irregular & 5.4 & Scattered & 14 \\
\hline 7. & $\begin{array}{l}\text { SRBW- } \\
1\end{array}$ & Fast & $\begin{array}{l}\text { Dull } \\
\text { White }\end{array}$ & $\begin{array}{l}\text { Aggregated, } \\
\text { dense cottony }\end{array}$ & 212.00 & \begin{tabular}{|l|} 
Dark \\
Brown
\end{tabular} & Spherical & 6.8 & Central & 9 \\
\hline 8. & $\begin{array}{l}\text { SRBW- } \\
2\end{array}$ & Moderate & $\begin{array}{l}\text { Cottony } \\
\text { White }\end{array}$ & $\begin{array}{l}\text { Upright growth } \\
\text { habit, cottony } \\
\text { \& puffy } \\
\text { aggregated }\end{array}$ & 178.00 & $\begin{array}{l}\text { Dull } \\
\text { Brown }\end{array}$ & Oval & 4.3 & Scattered & 12 \\
\hline 9. & SRPM-1 & Very Fast & White & $\begin{array}{l}\text { Suppressed, thin } \\
\text { strands }\end{array}$ & 395.00 & \begin{tabular}{|l|} 
Dark \\
Brown
\end{tabular} & Irregular & 8.6 & Scattered & 10 \\
\hline 10 & SRPM-2 & Fast & White & $\begin{array}{l}\text { Suppressed, thin } \\
\text { strands }\end{array}$ & 285.00 & \begin{tabular}{|l|} 
Dark \\
Brown \\
\end{tabular} & Spherical & 7.9 & Scattered & 13 \\
\hline
\end{tabular}


The isolates SRPU-1, SRBR-1 and SRBR-2 were produced light brown color sclerotia where as isolates SRPU-2, SRBN-2, SRBW1, SRPM-1and SRPM-2 produced Dark Brown sclerotia and SRBN-1, SRBW-2 were produced Dull Brown sclerotia. Six no of isolate i.e. SRPU-1, SRPU-2, SRBR-2, SRBW-2, SRPM-1 and SRPM-2 were shown Scattered sclerotial appearance where as SRBN-1 and SRBR-1 showed Peripheral and SRBN-2 and SRBW-1 showed Central sclerotial appearance on PDA medium. Sclerotial weight was range from $3.7 \mathrm{mg}$ to $8.6 \mathrm{mg}$. highest sclerotial weight $8.6 \mathrm{mg}$ was recorded in SRPM-1 and lowest $3.7 \mathrm{mg}$ recorded in SRBR-1 isolate. The maximum number, 395.00 no/plate of sclerotia production was recorded in SRPM-1 isolate and lowest 154.00 no./ plate was recorded in SRBR-1 isolate. Sclerotial maturity time was range from 9 to 15 days after inoculation. Fasted maturity 9 DAI recorded in SRBW-1 isolate and slowest maturity 15 DAI recorded in SRPU-1 and SRBR-1 isolates. The cultural and morphological characters of S.rolfsii isolates tested were highly variable. Variations in sclerotial colour, shape and size and their ability to infect plants have been reported by different scientists on various hosts and media (Sharma et al., 2002; Palaiah and Adiver 2006; Kumar et al., 2014). Geographical variability among S.rolfsii populations was demonstrated by earlier workers (Harlton et al., 1995; Okabe et al., 1998). Studies of variability within the population in a geographical region are important because these also document the changes occurring in the population. The significant variation in culture characteristics, mycelial morphology and pathogenicity amongst test isolates indicated that S.rolfsii can best be characterized by a combination of culture characteristics, morphology and virulence on host plants. The differences in sclerotial forming capacity among isolates could be a useful parameter for characterizing isolates, due to the fact that number of sclerotia formed among fungal isolates was significant (Horsfall, 1932).

In conclusion, the tomato collar rot causing pathogen $S$. rolfsii possesses wide diverse cultural, morphological and pathogenic variability which help it for wide rage adoptability and survivability in diverse ecological situation and it make very difficult to manage during crop production.

\section{References}

Barnett, H.L., Hunter, B.B. 1972. Illustrated genera of imperfect fungi. Burgess Publishing Company, Minnesota.

Cooper, W.E., 1961. Strains of resistance to antagonists of Sclerotium rolfsii Phytopathol., 51: 113-116.

Harlton, C.E., Levesque, C.A., Punja, Z.K. 1995. Genetic diversity in Sclerotium Athelia rolfsii and related species. Phytopathol., 85: 12691281.

Horsfall, J.G. 1932. Dusting tomato seed with copper sulphate monohydrate for combating damping off. Exp. Sta. Tech. Bull., 198: 1-34.

Kumar, M.R., Madhavi Santhoshi, M.V., Giridhara Krishna, T. and Reddy Raja, K.., 2014. Cultural and Morphological Variability Sclerotium rolfsii Isolates Infecting Groundnut and Its Reaction to Some Fungicidal. Int. J. Curr. Microbiol. App. Sci., 3(10): 553-561.

Okabe, I., Morikawa, C., Matsumoto, N., Yokoyama, K. 1998. Variation in Sclerotium rolfsii isolates in Japan. Mycosci., 39(4): 399407.

Palaiah, P., Adiver, S.S. 2006. Morphological and cultural variability in Sclerotium rolfsii sacc. Karnataka J. Agri. Sci., 19(1): 146148.

Rakholiya, K.B., Jadeja, K.B. 2011. Morphological diversity of Sclerotium rolfsii caused stem and pod rot of 
Groundnut. J. Mycol. Plant Pathol., 41(4): 500504.

Rangaswami, G., Mahadevan, A. 1999. Diseases of crop plants in India. Prentice Hall of India Pvt. Ltd., New Delhi. 6079 Pp.

Rolfs, P.H., 1892. Tomato blight: some hints.

Bulletin Fla. Agric. Experimentation Station, p.18.

Saccardo, P.A., 1911. Notae Mycological. Annales Mycologici, 9: 249-257.

Sharma, B.K., Singh, U.P., Singh, K.P. 2002. Variability in Indian isolates of
Sclerotium rolfsii. Mycologia, 946: 10511058.

Tu, J.C. 1978. Production of soybean from severe root-rot by Rhizobium. Physiol. Plant Pathol., 12: 233-240.

Tuite, J. 1996. Plant Pathological Methods. Fungi and Bacteria Burgess Pub. Co. Minneapolis, Minn. USA. 293pp.

Wydra, K. 1996. Collection and determination of root and stem rot pathogens. Annuals report II T.A., Ibadan, Nigeria. 6.

\section{How to cite this article:}

Asish Mahato and Mohan Kumar Biswas. 2017. Cultural, Morphological and Pathogenic Variability of different Isolates of Sclerotium rolfsii Obtained from Rice - Tomato -Rice Cropping System of Undulating Red and Lateritic Zone of West Bengal, India.

Int.J.Curr.Microbiol.App.Sci. 6(3): 1843-1851. doi: https://doi.org/10.20546/ijcmas.2017.603.210 